\title{
CORRECTION
}

\section{Correction to: Application of Jute-Polypropylene Blended Geotextile in Black Cotton Soil Subgrade for Low Volume Road Construction}

\author{
Mahuya Ghosh $^{1}$ (D) Rumki Saha ${ }^{1} \cdot$ Monimoy Das ${ }^{1}$
}

Published online: 14 September 2021

(c) Springer Nature Switzerland AG 2021

\section{Correction to: \\ International Journal of Geosynthetics and Ground Engineering \\ https://doi.org/10.1007/s40891-021-00301-x}

In the original publication of the article, in Table 3, the last column containing the ASTM and IS standard details (embedded references from [55] to [65] are missing in the table text) has been missed out. The correct Table 3 is given below:

Table 3 Geotechnical properties of the experimental black cotton soil

\begin{tabular}{lll}
\hline Soil properties & Results & Test method \\
\hline Liquid limit (\%) & 68 & IS:2720 (Part 5):1985 [55], similar to ASTM D4318:2017 [56] \\
Plastic limit (\%) & 32 & \\
Plasticity index (\%) & 36 & IS:2720 (Part 6):1972 \\
Shrinkage limit (\%) & 11.7 & Reaffirmed 2001 [57] \\
& 22 & IS:2720 (Part 4):1985 [58], similar to ASTM D6913/ \\
Sand (\%) & 19 & D6913M:2017 [59] and D7928:2017 [60] \\
Silt (\%) & 59 & \\
Clay (\%) & CLAY sandy silty & IS:1498:1970 [61], similar to ASTM D2487:2017 [62] \\
Soil classification & 34 & IS:2720 (Part 7):1980 [63], similar to ASTM D698:2012 [64] \\
Optimum moisture content, OMC (\%) & 13 & \\
Maximum dry density, MDD $\left(\mathrm{kN} / \mathrm{m}^{3}\right)$ & 50 & IS:2720 (Part 40) 1977 [65] \\
Free swell index $(\%)$ & &
\end{tabular}

The original article can be found online at https://doi.org/10.1007/ s40891-021-00301-x.

Mahuya Ghosh

mahuya.g@gmail.com

1 Geotech Cell, Indian Jute Industries' Research Association (IJIRA), 17 Taratala Road, Kolkata 700088, India 